\title{
THE PROBLEMS OF THE USE OF FOOD ADDITIVES IN THE INFANT'S FOODSTUFFS
} Ivakhno A.P., Koziarin I.P.

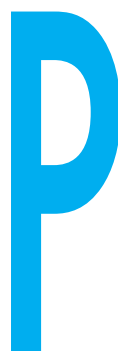

IBAXHO O.П., КОЗЯРІН І.П.

Національна медична академія

післядипломної освіти

ім. П.Л. Шупика м. Київ

Ключові слова: діти, дитяче харчування, харчові добавки, спеціальні

продукти харчування.

\section{ПРОБЛЕМИ ВИКОРИСТАННЯ ХАРЧОВИХ ДОБАВОК У ПРОДУКТАХ ДИТЯЧОГО ХАРЧУВАННЯ}

аціональне харчування $€$ одним з важливих і невід'ємних компонентів здорового способу життя, яке забезпечує збереження здоров'я і високу працездатність людини. Особливе значення має правильне харчування у дитячому віці, коли формуються основні фізіологічні, метаболічні, імунологічні механізми, які забезпечують сталість гомеостазу організму дитини.

у зв'язку з цим зрозумілими є зацікавленість і увага батьків і медичних працівників до рекомендацій щодо дитячого харчування, яке $\epsilon$ одним 3 ключових чинників, що визначають темпи росту дитини, ї̈ гармонійний розвиток, стійкість до дії інфекційних та інших факторів навколишнього середовища. Тому харчовий раціон дітей має містити усі харчові речовини в оптимальних співвідношеннях [3, 4, 6, 10].

Загальні кількості харчових речовин та їхня добова енергетична цінність для дітей різних вікових груп затверджені Наказом МO3 України № 1073 від 03.09.2017 р. «Норми фізіологічних потреб населення України в основних харчових речовинах і енергії» (табл. 1) [9].

Численними дослідженнями доведено, що їжа для людини - це складний комплекс тисяч хімічних сполук, які містять властиві для харчового продукту (ХП) речовини, що мають різні властивості і проявляють різнобічну дію на організм. Однак не дивлячись на різноманітність ХП існує загальний для усіх продуктів набір основних груп інгреді- єнтів (рис. 1). 3 рисунка 1 видно, що основу ХП складають природні харчові речовини. Проте до складу багатьох ХП випадково можуть потрапляти чужорідні токсичні для людини речовини у вигляді контамінантів (забруднювачів), а інколи, за технологічної необхідності, їх вводять спеціально у вигляді харчових добавок (ХД).

Контамінантами ХП називають речовини хімічної природи, що надходять із довкілля і потрапили до їжі до її приготування, під час чи після. Усі контамінанти і харчові добавки зазвичай об'єднують загальним терміном «сторонні речовини», або «ксенобіотики». З позиції токсикології поняття про ксенобіотики і шкідливі речовини практично співпадають [7, 8].

Мета роботи. Викладене вище спонукало провести аналіз даних наукової літератури відносно використання харчових добавок у раціонах дітей молодшого віку.

Матеріали та методи досліджень. На сьогодні ХД сотень найменувань використовують усі галузі харчової промисловості у виробництві, переробці, приготуванні, пакуванні, зберіганні, транспортуванні та реалізації ХП. Тому ХД потребують ретельного вивчення та відповідного контролю над їх використанням з метою запобігання захворюванням споживачів, враховуючи їхню різну чутливість і реактивність організму, особливо дітей раннього віку $[2,5,7,11,12]$.
ПРОБЛЕМЫ ИСПОЛЬЗОВАНИЯ ПИЩЕВЫХ ДОБАВОК В ПРОДУКТАХ ДЕТСКОГО ПИТАНИЯ

Ивахно А.П., Козярин И.П.

Национальная медицинская академия последипломного образования им. П.Л. Шупика, г. Киев, Украина

В работе приведены данные об использовании пищевых добавок в рационах питания детей младшего возраста, их классификация, влияние на организм, меры по предупреждению отрицательного действия.

Цель работы: анализ данных научных исследований по использованию пищевых добавок в рационах питания детей младшего возраста.

Материалы и методы: проанализированы данные научных исследований по использованию пищевых добавок в питании детей раннего возраста.
Результаты. Пищевые добавки широко используются во всем мире, но количество разрешенных для изготовления специальных продуктов питания для детей значительно ограничено, особенно это относится к красителям, ароматизаторам, подсластителям и заменителям сахара.

Выводы. В Украине до настоящего времени нет эффективного и действенного контроля выпуска и использования пищевых добавок, особенно при изготовлении продуктов детского питания. Отдельные проверки не позволяют полностью гарантировать выполнение утвержденных стандартов производителями и полное исключение ситуаций, при которых они могут использовать запрещенные к применению пищевые добавки.

Ключевые слова: дети, детское питание, пищевые добавки, специальные продукты питания.

๑ Івахно О.П., Козярін І.П. СТАТТЯ, 2019.

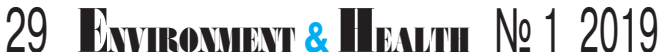


Відповідно до визначення, даного фахівцями ВОО3, членом якої є і Україна, «харчова добавка - це речовина, що не використовується для їжі у чистому вигляді і не є типовим інгредієнтом продуктів харчування незалежно від того, має ця речовина поживні властивості чи ні, яка навмисно вводиться до ХП з технологічною метою у процесі їх обробки, виготовлення, пакування, транспортування чи зберігання або яка може безпосередньо чи опосередковано забезпечити потрібний результат і вплинути на характеристику таких продуктів» $[2,5,11]$.

До ХД не належать речовини, які підвищують харчову цінність продуктів (вітаміни, амінокислоти, органічні кислоти, біомікроелементи) або надають їм нових функціональних ознак, перетворюючи на продукти спеціального медико-біологічного призначення [2, 7].

Харчові добавки за походженням поділяють на 2 групи: природні і синтетичні, а за призначенням - на 3 групи, які поліпшують консистенцію та органолептичні показники продуктів, підвищують стійкість ХП під час зберігання та подовжують терміни зберігання, поліпшують технологію виробництва продуктів тощо.

Доцільно зазначити, що у харчовому продукті одна й та сама добавка може виконувати декілька функцій. Тому віднесення тієї чи іншої ХД до певного функціонального класу визначається основною функцією, яку вона виконує у харчовому продукті $[2,4,11]$.

Нині харчова промисловість України виробляє відповідний асортимент спеціалізованих продуктів для дитячого і дієтичного харчування, у тому числі і для дітей самого раннього віку та дітей, які страждають на деякі захворювання.

Однак промислове виробництво готових до споживання продуктів, страв та напівфабрикатів для дітей перших трьох років життя має свої технологічні і гігієнічні особливості. Спеціалізовані продукти для дитячого і дієтичного харчування повинні мати високу харчову і біологічну цінність та забезпечувати потре- би організму дитини, що швидко росте і розвивається. Водночас дані продукти мають відповідати біохімічним, а також анатомофізіологічним і функціональним особливостям організму дитини $[5,7,11,12]$. Тому однією з найважливіших гігієнічних особливостей виробництва спеціалізованих продуктів для дитячого і дієтичного харчування $є$ обмеження використання харчових добавок. Перелік ХД, дозволених для виготовлення продуктів дитячого харчування, містить лише декілька найменувань пектин, лимонна кислота, ванілін тощо, тоді як решта добавок ароматизаторів, за винятком натуральних, включати до складу продуктів дитячого харчування категорично заборонено [7, 11, 12].

Використання ХД у сумішах для дітей перших років життя регулюється суворими приписами, викладеними у Директиві 89/398/ЕЕС від 03.05.1989 р. щодо приведення у відповідність законодавчих актів держав-учасниць ЄС стосовно продуктів харчування, призначених для спеціального харчування. Останні і

Таблиця 1

Добова потреба дитячого населення у білках, жирах, вуглеводах та енергї̈

\begin{tabular}{|c|c|c|c|c|c|c|}
\hline \multirow[b]{2}{*}{ Вікова група } & \multirow[b]{2}{*}{ Стать } & \multirow{2}{*}{$\begin{array}{c}\text { Енергія, } \\
\text { ккал }\end{array}$} & \multicolumn{2}{|c|}{ Білки, г } & \multirow{2}{*}{$\begin{array}{c}\text { Жири, } \\
\text { г }\end{array}$} & \multirow{2}{*}{$\begin{array}{c}\text { Вуглеводи, } \\
\text { г }\end{array}$} \\
\hline & & & $\begin{array}{l}\text { Загальна } \\
\text { кількість }\end{array}$ & Тваринні & & \\
\hline 0-3 місяці* & Хлопчики та дівчатка & 120 & 2,2 & 2,2 & 6,5 & 13 \\
\hline 4-6 місяців* & Хлопчики та дівчатка & 115 & 2,6 & 2,5 & 6,0 & 13 \\
\hline 7 - 12 місяців & Хлопчики та дівчатка & 110 & 2,9 & 2,3 & 5,5 & 13 \\
\hline 1-3 роки & Хлопчики та дівчатка & 1385 & 53 & 37 & 44 & 194 \\
\hline 4-6 років & Хлопчики та дівчатка & 1700 & 58 & 41 & 56 & 240 \\
\hline 6 років (учні) & Хлопчики та дівчатка & 1800 & 60 & 43 & 58 & 260 \\
\hline 7-10 років & Хлопчики та дівчатка & 2100 & 72 & 51 & 70 & 295 \\
\hline \multirow{2}{*}{ 11-13 років } & Хлопчики & 2400 & 84 & 62 & 84 & 327 \\
\hline & Дівчатка & 2300 & 78 & 55 & 76 & 326 \\
\hline \multirow{2}{*}{ 14-17 років } & Юнаки & 2700 & 93 & 68 & 92 & 375 \\
\hline & Дівчата & 2400 & 83 & 59 & 81 & 334 \\
\hline
\end{tabular}

Примітка: * - для дітей 0-12 місяців життя потреби наведено з розрахунку на 1 кілограм маси тіла.

Рисунок

Основні компоненти харчових продуктів (Тутельян В.Л., 2004 р.)

\begin{tabular}{|c|c|c|}
\hline $\begin{array}{l}\text { Харчові } \\
\text { добавки }\end{array}$ & $\begin{array}{c}\text { Біологічно активні } \\
\text { мінорні компоненти }\end{array}$ & $\begin{array}{c}\text { Антиаліментарні } \\
\text { чинники }\end{array}$ \\
\hline$\uparrow$ & $\uparrow$ & $\lambda$ \\
\hline \multicolumn{3}{|c|}{ Основні компоненти харчових продуктів } \\
\hline \multicolumn{2}{|c|}{ 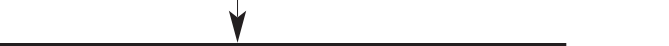 } & $\gamma$ \\
\hline \multicolumn{2}{|c|}{$\begin{array}{c}\text { Харчові речовини (білки, жири, } \\
\text { вуглеводи, вітаміни, мінеральні } \\
\text { речовини і мікроелементи) }\end{array}$} & $\begin{array}{c}\text { Нехарчові } \\
\text { компоненти }\end{array}$ \\
\hline
\end{tabular}

продукти для підгодовування немовлят та маленьких дітей можуть містити такі ХД, як гуміарабік (Є 414) та діоксид кремнію (Є 551). При цьому готові страви, з яких складається таке харчування, не повинні містити кожної з цих речовин понад 10 г/кг. Дозволяється додавати до ХП $€ 421$ (маніт), оскільки він діє як речовина-основа для вітаміну $\mathrm{B}_{12}$ (співвідношення «вітамін $\mathrm{B}_{12}$ : 
THE PROBLEMS OF THE USE OF FOOD ADDITIVES IN THE INFANT'S FOODSTUFFS

Ivakhno A.P., Koziarin I.P.

National P.L. Shupyk Medical Academy

of Postgraduate Education, Kyiv

The article presents the data on the use of food additives in the infant's food intakes, their classification, effects on the organism, measures for the prevention of negative impact.

Objective: We analysed the research data on the use of food additives in the food intakes of the infants.

Materials and methods: We analyzed the data of the scientific research on the use of food additives in the nutrition of the infants.
Results: Nutritional additives are widely used throughout the world but the number of special foods for the children allowed for the manufacture for the children is significantly limited, especially in dyes, flavors, sweeteners, and sugar substitutes. Conclusions: There is no effective control of the production and use of food additives, especially in the manufacture of the infant's food in Ukraine until now. Separate inspections do not allow a full guarantee of the fulfillment of approved standards by the manufacturers and a complete elimination of the situations where they may use prohibited food additives.

Keywords: children, infant's food, food additives, special foodstuffs. маніт» не має перевищувати 1:1000). Перелік ХД, дозволених до використання у продуктах харчування для немовлят, наведено у таблиці 2.

Для отримання ХП для дитячого харчування з відповідною густиною (в'язкістю) дозволяється використовувати деякі загущувачі, передусім природні високомолекулярні полісахариди: камеді, пектини та модифіковані крохмалі, які не мають обмежень за токсикологічними показниками. 3 метою стабілізації колоїдних систем рідких і пастоподібних ХП дозволяється використання високоочищених лугів, карбонатів, цитратів. Із харчових кислот доцільно використовувати лимонну, оцтову і молочну, а в якості розпушувачів - карбонат чи гідрокарбонат амонію. У якості антиокислювачів (антиоксидантів) рекомендуються речовини, що мають антиоксидантні властивості та вітамінну активність (аскорбінова кислота та її солі, $\alpha$-токоферол чи суміш токоферолів). 3 цієї групи ХД забороняються для використання бутилгідроокситолуол чи бутилгідрооксианізол, галлати, хімічні консерванти, нітрити, нітрати 3 урахуванням їхньої хімічної і біологічної активності $[2,8,11]$.

Особливої уваги потребує питання використання харчових добавок, які впливають на органолептичні властивості продуктів (барвники, ароматизатори, підсолоджувачі), оскільки при виробництві продуктів для дитячого харчування їх застосування дуже обмежене. Категорично забороняється використання синтетичних барвників. Для надання ХП привабливого вигляду і запаху доцільно використовувати натуральні фруктові концентрати та про- дукти переробки плодів і овочів (екстракти). Для виготовлення окремих продуктів обмежено дозволяється використання ваніліну і етилваніліну $[2,5]$.

Надзвичайної уваги при виготовленні спеціальних і звичай-

них продуктів дитячого харчування потребує проблема застосування підсолоджувачів і замінників цукру, насамперед для дітей віком до 3-х років.

Цукрозамінники допускаються для використання у спеціалізо-

Таблиця 2

Харчові добавки, дозволені для використання у харчуванні здорових немовлят на початковій та подовжених стадіях годування (Директива 89/398/EEC)

\begin{tabular}{|c|c|c|}
\hline Індекс & $\begin{array}{c}\text { Назва } \\
\text { добавки }\end{array}$ & $\begin{array}{c}\text { Максимально } \\
\text { дозволений рівень }\end{array}$ \\
\hline \multicolumn{3}{|c|}{ На початковій стадії } \\
\hline $\begin{array}{l}\epsilon 270 \\
\epsilon 330 \\
\epsilon 338\end{array}$ & $\begin{array}{l}\text { Молочна кислота (тільки L(+) - } \\
\text { молочна кислота) } \\
\text { Лимонна кислота } \\
\text { Фосфорна кислота }\end{array}$ & $\begin{array}{c}\text { За технологічної } \\
\text { необхідності } \\
-- \\
\text { Згідно з граничними значен- } \\
\text { нями Директиви 91/321/EЕC }\end{array}$ \\
\hline $\begin{array}{l}\Theta 306 \\
\epsilon 307 \\
\epsilon 308\end{array}$ & $\begin{array}{l}\text { Концентрат суміші токоферолів } \\
\text { Альфа-токоферол } \\
\text { Гамма-токоферол }\end{array}$ & $\begin{array}{l}10 \text { мг/л окремо } \\
\text { чи в комбінації }\end{array}$ \\
\hline$\epsilon 309$ & Дельта-токоферол & 10 мг/л окремо чи у комбінації \\
\hline $\begin{array}{l}€ 322 \\
€ 471\end{array}$ & $\begin{array}{l}\text { Лецитин } \\
\text { Моно- та дигліцериди жирних кислот }\end{array}$ & $\begin{array}{l}1 \text { г/л } \\
4 \text { г/л }\end{array}$ \\
\hline \multicolumn{3}{|c|}{ На продовженій стадії годування } \\
\hline $\begin{array}{l}\Theta 270 \\
\text { € } 330\end{array}$ & $\begin{array}{l}\text { Молочна кислота (тільки L(+) - } \\
\text { молочна кислота) } \\
\text { Лимонна кислота }\end{array}$ & $\begin{array}{c}\text { За технологічної } \\
\text { необхідності } \\
--\end{array}$ \\
\hline $\begin{array}{l}\epsilon 306 \\
\epsilon 307 \\
\epsilon 308 \\
\epsilon 309\end{array}$ & $\begin{array}{l}\text { Концентрат суміші токоферолів } \\
\text { Альфа-токоферол } \\
\text { Гамма-токоферол } \\
\text { Дельта-токоферол }\end{array}$ & $\begin{array}{l}10 \text { мг/л окремо } \\
\text { чи у комбінації }\end{array}$ \\
\hline$€ 338$ & Фосфорна кислота & $\begin{array}{l}\text { Згідно з граничними значен- } \\
\text { нями Директиви 91/321/EEC }\end{array}$ \\
\hline$€ 440$ & Пектин & $\begin{array}{c}5 \text { г/л тільки у кисломолочному } \\
\text { харчуванні подовженої } \\
\text { стадії годування }\end{array}$ \\
\hline $\begin{array}{l}€ 322 \\
€ 471\end{array}$ & $\begin{array}{l}\text { Лецитин } \\
\text { Моно- та дигліцериди жирних кислот }\end{array}$ & $\begin{array}{l}1 \text { г/л } \\
4 \text { г/л }\end{array}$ \\
\hline $\begin{array}{l}€ 407 \\
€ 410 \\
€ 412\end{array}$ & $\begin{array}{l}\text { Карагінан } \\
\text { Камедь рожкового дерева } \\
\text { Гуарова камедь }\end{array}$ & $\begin{array}{l}0,3 \text { г/л } \\
1 \text { г/л } \\
1 \text { г/л }\end{array}$ \\
\hline
\end{tabular}

Примітка: для виготовлення кислого молока можуть використовуватися непатогенні культури, що виробляють $L(+)$ молочну кислоту, а якщо до продукту харчування додаються ще інші речовини, разом з однією із речовин $€ 322, \epsilon 471, € 407$, $€ 410$ i 4 412, то від максимальної кількості кожної з них, встановленої для цього продукту харчування, необхідно відняти ту кількість, якій дорівнює відповідно вміст інших речовин у цьому продукті харчування. 
ваних продуктах дитячого харчування лише за умов, коли дитині за станом здоров'я протипоказане споживання цукру. Необхідно враховувати той факт, що для дітей не тільки перших трьох років життя, але й старших прості та складні цукри $€$ необхідним компонентом харчового раціону. Тому використання цукрозамінників небажане, бо це суперечить основам раціонального харчування [2, 5, 10, 12].

Слід пам'ятати, інтенсивність обміну речовин у дітей у декілька разів вища, ніж у дорослих, відповідно при розрахунку на одиницю маси тіла діти споживають більше вуглеводів і цукру.

Діти, хворі на цукровий діабет та інші захворювання, потребують регламентації добових доз замінників цукру і підсолоджувачів [1, 2, 11]. Згідно з рекомендацією Об'єднаного Комітету ФАО/ВООЗ з харчових добавок питання про оптимальні дози для підсолоджувачів і цукрозамінників передбачають гарантії безпеки і для організму дитини, і для вагітних, і для жінок, які вигодовують дітей грудним молоком (табл. 3).

\section{Висновки}

1. Контроль над виробництвом та застосуванням харчових добавок в Україні покладено на Державну службу 3 питань безпечності харчових продуктів та захисту споживачів і МОЗ України.

2. Вибіркові перевірки, передбачені чинними механізмами держнагляду, не дозволяють повністю гарантувати належне дотримання затверджених стандартів у виробництві та цілковите виключення ситуації, за якої виробники можуть використовувати не дозволені до застосування харчові добавки.

3. Застосування підсолоджувачів дає змогу розширити асортимент харчовихпродуктів для дітей, хворих на цукровий діабет та 3 надмірною масою тіла за умов

Рекомендовані добові дози підсолоджувачів, згідно з побажаннями Комітету ФАО/ВООЗ з ХД

\begin{tabular}{|c|c|}
\hline Назва підсолоджувача & Рекомендована добова доза, мг/кг маси тіла \\
\hline Аспартам & 40 \\
\hline Сахарин & 5 \\
\hline Цикламати & 11 \\
\hline Сукралоза & 18 \\
\hline Ацесульфам K & 8 \\
\hline
\end{tabular}

жорсткого контролю над їх використанням під час виробництва. ЛІТЕРАТУРА

1. Адамчук Т.В. Підсолоджувачі та принципи їх регламентування. Проблеми харчування. 2003. № 1. С. 68-70.

2. Булдаков А.С. Пищевые добавки. Справочник. 2-е изд. переработанное и дополненное. М. : ДеЛи Принт, 2001. 436 с.

3. Волошин О.І., Сплавський О.І. Основи оздоровчого харчування. Чернівці : Букрек, 2006. 304 c.

4. Гігієна харчування:

Практичне керівництво / за ред. Ванханена В.Д. і

Ципріяна В.І. Донецьк :

Донеччина, 2005. 552 с.

5. Гігієна харчування з основами нутриціології : підручник у 2-х кн. / за ред. В.І. Ципріяна. К. : Медицина, 2007. Кн. 2. C. 227-250.

6. Гребняк М.П. Профілактична медицина дітей та підлітків. Дніпропетровськ : Пороги, 2013. 388 с

7. Європейські вимоги до харчових добавок. Довідник. Львів : Леонорм, 1997. 126 с

8. Кобзар А.Я., Корзун В.Н., Карандєєва Н.І., Дзюба Є.О. Харчові добавки: віддалена загроза. Довкілля та здоров'я. 2013. № 1. С. 70-74.

9. Про затвердження Норм фізіологічних потреб населення України в основних харчових речовинах і енергії : Наказ МО3 України № 1073 від 03.09.2017 URL : https://zakon.rada.gov. ua/laws/show/z1206-17

10. Нэйра П. Рациональное питание. Харків, 2005. 382 с.

11. Руководство по детскому питанию / под ред. В.А. Тутельяна. М. : Медицинское информационное агентство, 2004. 662 c.

12. Смоляр В.І. Фізіологія та гігієна харчування. Київ :

Здоров'я, 2000. 335 с.

REFERENCES

1. Adamchuk T.V. Problemy kharchuvannia. $2003 ; 1: 68-70$ (in Ukrainian)

абиця 3

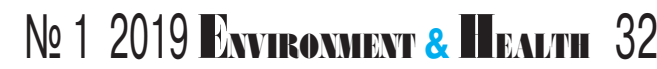

2. Buldakov A.S. Pishchevye dobavki. Spravochnik. 2-nd ed. [Dietary Additives. Reference Book. 2-nd Ed.]. Moscow : DeLiPrint ; 2001 : 436 p. (in Russian).

3. Voloshyn O.I. and Splavskyi O.I. Osnovy zdorovoho kharchuvannia [Background of Healthy Nutrition]. Chernivtsi : Bukrek; 2006 : 304 p. (in Ukrainian).

4. Vankhanen V.D. and Tsypriian V.I. (eds.) Hihiiena kharchuvannia: Praktychne kerivnytstvo [Food Hygiene: Practical Guide]. Donetsk : Donechchyna ; 2005 : 552 p. (in Ukrainian).

5. Tsypriian V.I. (ed.) Hihiiena kharchuvannia z osnovamy nutrytsiolohii : pidruchnyk [Food Hygiene with the Background of Nutritiology: Manual]. Kyiv : Medytsyna ; 2007 ; Book 2 : 227-250 (in Ukrainian).

6. Hrebniak M.P. Profilaktychna medytsyna ditey ta pidlitkiv [Preventive Medicine for Children and Adolescents]. Dnipropetrovsk : Porohy ; 2013 :

7. Yevropeiski vymohy do kharchovykh dobavok [European Requirements to the Dietary Additives. Reference Book]. Lviv : Leonorm ; 1997 : 126 p. (in Ukrainia).

8. Kobzar A.Ya., Korzun V.N. Karandieieva N.I. and Dziuba Ye.O. Dovkillia ta zdorovia (Environment and Health). 2013 ; 1 ; 70-74 (in Ukrainian).

9. Pro zatverdzhennia Norm fiziolohichnykh potreb naselennia Ukrainy v osnovnykh kharchovykh rechovynakh i enerhii : Nakaz MOZ Ukrainy № 1073 vid 03.09.2017 [On the Approval of the Norms of Physiological Needs of the Population of Ukraine in the Main Nutrients and Energy: Order of the Ministry of Health of Ukraine № 1073, September 3, 2017]. URL: https://zakon.rada.gov.ua/laws/

(in Ukrainian)

10. Neira P. Ratsionalnoe pitanie [Balanced Diet]. Kharkov ; 2005 : 382 p. (in Russian). 11. Tutelian V.A. (ed.) Rukovodstvo po detskomu pitaniyu [Guide on Infant Food]. Moscow: Meditsinskoe informatsionnoe agenstvo ; 2004 : 662 p. (in Russian).

12. Smoliar V.I. Fiziolohiia ta hihiiena kharchuvannia [Physiology and Food Hygiene ]. Kyiv : Zdorovia ; $2000: 335$ p. (in Ukrainian). Надійшла до редакції 15.11.2018 388 p. (in Ukrainian). show/z1206-17 